\title{
w rosyjskojęzycznym Internecie a kwestia popularności
}

W ostatnich latach pojawiły się w Polsce prace podejmujące problematykę przekładu poezji Bolesława Leśmiana na inne języki, w tym na rosyjski. Są to jednak przede wszystkim liczne artykuły oraz monografia Marty Kaźmierczak $^{1}$, a także jeden z rozdziałów książki Iriny Jermaszowej², która analizuje rosyjskie warianty wierszy poety w kontekście rozważań nad metodą translatorską Natalii Astafiewej i Władimira Britaniszskiego. Pozwolę sobie nie wymieniać pozostałych, pomniejszych prac przekładoznawczych, ponieważ nie to jest przedmiotem moich badań. Ich celem jest natomiast uzupełnienie wcześniejszych rozważań o relację dotyczącą rosyjskojęzycznego Internetu, w którym, jak twierdzą niektórzy, można znaleźć wszystko bądź prawie wszystko. Niemniej nie wszystko, co tam opublikowano, ma taką samą wartość, dlatego też podeszłam do proponowanych badań wybiórczo, zakładając wstępnie, że przyjrzę się przede wszystkim stronom internetowym specjalizującym się w prezentacji obcej poezji w tłumaczeniach, takim jak Стихи.py, Поэзия.py czy też projekt „Век перевода”. W procesie analizy okazało się jednak, że powinnam zwrócić uwagę także na kilka innych autorskich stron, na których zamieszczono większą liczbę przekładów, jak również innego rodzaju wzmianek o Leśmianie.

\footnotetext{
" Uniwersytet Łódzki, Instytut Rusycystyki, Zakład Przekładu i Dydaktyki, e-mail: anbednar@o2.pl.

1 M. Kaźmierczak, Przekład w kreggu intertekstualności. Na materiale tłumaczeń poezji Bolesława Leśmiana, Warszawa 2012.

2 I. Jermaszowa, Leśmian w pięcioprzekładowej „pigułce” Astafjewej, [w:] tejże, Polska poezja w rosyjskim dwugłosie. O tłumaczeniach Natalii Astafjewej i Wladimira Britaniszskiego, Poznań 2016, s. 106-129.
} 
Na podstawie tego materiału chciałabym przeanalizować kwestie związane $\mathrm{z}$ występowaniem dzieł polskiego poety w rosyjskojęzycznej przestrzeni cyfrowej, ponieważ współcześnie obecność w globalnej sieci przekłada się na popularność danego autora i konkretnej twórczości. Tak też dzieje się w przypadku Leśmiana i rosyjskojęzycznych czytelników. Ciekawe, że często owa popularność nie wiąże się ani z profesjonalizmem tłumacza, ani z jakością rosyjskich wariantów. Trzeba przy tym wspomnieć, że w Internecie pojawiają się zarówno prace znanych tłumaczy, jak i propozycje amatorów, a przekłady publikowane na stronach www charakteryzuje, eufemistycznie mówiąc "różnorodność jakości".

Sądzę, że przebadanie zawartości choćby części rosyjskojęzycznych stron internetowych zawierających propozycje translatorskie, ale także komentarze i informacje o Leśmianie, może wspomóc badania nad popularnością poety w tym obszarze językowym. Co ciekawe, z moich obserwacji wynika, że zainteresowanie polską poezją (nie tylko twórczością Leśmiana) wśród rosyjskojęzycznych użytkowników Internetu rośnie w ostatnich latach niezależnie od stanu polsko-rosyjskich stosunków dyplomatycznych.

Warto odnotować, że poza przekładami w Internecie znajdujemy informacje o tłumaczeniach, które ukazały się drukiem w Rosji, a wcześniej w ZSRR. Można więc pokusić się o odpowiedź na pytanie, jakiego Leśmiana poznaje dzisiejszy rosyjskojęzyczny czytelnik, co z kolei wiąże się zarówno z wyborem tekstów, jak i z pewnymi wyznacznikami jakości tłumaczenia. Jednak w związku z tym, że na rosyjski została przełożona niemal cała twórczość poety, pytanie brzmi nie tyle "co", ile „jak” Leśmiana przełożono? Tą kwestią nie będę się jednak zajmować w niniejszym studium.

W tym miejscu trzeba jeszcze zauważyć, że duża część publikowanych w cyberprzestrzeni przekładów to teksty wcześniej już zaistniałe, na przykład w zbiorach poezji czy na łamach czasopism. Dlatego też wszelkie obecne w Internecie tłumaczenia należy moim zdaniem podzielić na posiadające wcześniejszy wariant papierowy oraz opublikowane wyłącznie w cyberprzestrzeni, ale także ze względu na stopień anonimowości autora i stopień ukształtowania przekładu, ponieważ zdarzają się różne wersje translatorskie, poprawiane na kolejnych etapach pracy.

Kwestia anonimowości wiąże się z tym, że tłumaczenia elektroniczne mogą, ale nie muszą być podpisane nazwiskiem tłumacza. Pomijam tu problem prawa autorskiego, zdarza się bowiem, że autorami owych anonimowych wersji są znani przekładowcy, których prace publikowano wcześniej, ale administrator danej strony pominął informację o autorze rosyjskiego wariantu. Stosunkowo często pojawiające się w Internecie przekłady bywają też podpisywane pseudonimem - czasami nawet jedna osoba posługuje się kilkoma. W niektórych przypadkach można odnaleźć nazwisko tłumacza, w innych starania o jego zidentyfikowanie nie przynoszą żadnych rezultatów. Dlatego w niniejszym tekście odnoszę się do tych przekładów, które podpisane są nazwiskiem bądź stałym pseudonimem autora, tym bardziej że często nie można stwierdzić prawdziwości faktów 
podanych na stronie internetowej. Taką gwarancję daje chyba jedynie projekt „Век перевода”, prezentujący prace znanych rosyjskich tłumaczy poezji. W pewnym stopniu za wiarygodne można uznać również Cmuxu.py oraz Поэзия.py i autorskie strony tłumaczy, na których znalazły się informacje biograficzne.

Można to doskonale zilustrować, posługując się licznymi przykładami, spośród których wybrałam kilka. Pierwszy z nich to słowa anonimowego autora podpisanego pseudonimem Классика_ zamieszczone na stronie internetowej wraz z równie anonimowymi tłumaczeniami wierszy Leśmiana:

P.S. K сожалению не могу указать имена всех переводчиков данных стихов Б. Лесьмяна, ибо часть этих стихов написана автором по-русски (Лесьмян двадцать лет жил и учился в Киеве, поэтому русский - его второй родной язык), часть переведена А. Гелескулом, а остальных переводчиков я не знаю. Поэтому решил вообще не указывать переводчиков ${ }^{3}$.

Innym przykładem tłumacza podpisującego się pseudonimem (nickiem) jest alsit25. W tym przypadku nazwisko udało się odnaleźć, to mieszkający obecnie w USA inżynier z wykształcenia, Alex Sitnitsky. Zamieścił on na swojej stronie dziesięć przekładów wierszy Leśmiana ${ }^{4}$. Można także przeczytać na niej komentarze tłumacza, na przykład informację o stosowanych przez polskiego poetę neologizmach, ale również śledzić dyskusje z czytelnikami, w tym z innymi tłumaczami Leśmiana, na przykład z Lwem Bondariewskim, mieszkającym w Izraelu inżynierem elektrykiem, który podpisuje się lebo35. Przytoczę fragment jednej z nich, podczas której panowie wymieniają się uwagami na temat swoich przekładów Ballady bezludnej, przy okazji „przyszywając łatkę” innej tłumaczce tego tekstu - Iris Wirtualis:

lebo35 [Bondariewski - A.В.]: Поздравляю! С нём рождения и с хорошим переводом!

alsit25 [Sitnitsky - A.В.]: спасибо! хороший у вас вариант, а у меня адекватный оригиналу. Вы даже слово Июнь не поняли, что об остальном говорить!

lebo35 [Bondariewski - А.В.]: Оставляю Вам июнь. Ваше изобретение. [...]

3 P.S. К сожалению... - P.S. Niestety nie mogę wskazać nazwisk wszystkich tłumaczy cytowanych wierszy B. Leśmiana, ponieważ część z nich została napisana przez poetę po rosyjsku (Leśmian przez dwadzieścia lat mieszkał i uczył się w Kijowie, dlatego rosyjski jest jego drugim językiem ojczystym), część przełożył A. Gieleskuł, a pozostałych tłumaczy nie znam. Dlatego zdecydowałem się na to, by wcale nie wskazywać tłumaczy. Классика_, Болеслав Лесьмян, [w:] Стихи для ^юDей, http://stihidl.ru/poem/323803 (dostęp: 22.10.2017). Wszystkie przekłady rosyjskich cytatów zostały wykonane przez autorkę tekstu (A.B.).

4 alsit25, https://alsit25.livejournal.com/tag/Лесьмян (dostęp: 22.10.2017). 
alsit25 [Sitnitsky - A.В.]: ...а зеркала бывают кривые! я видел два - в вашем исполнении и незабвенной виртухалис ${ }^{5}$

gdzie słowo „wirtuchalis” (ros. виртухалис) zawiera odniesienia do nazwiska/pseudonimu Wirtualis, a zarazem do współczesnego slangu komputerowego (вир - to zgodnie z różnymi rosyjskimi słownikami ‘wirus komputerowy'6), ale także do żargonowego виртухаться [wirtuchat'sa], czyli 'wiercić się,', 'plątać, 'kręcić' (także wokół kogoś) i wreszcie do używanego w odesskim żargonie, pochodzącego z jidysz, тухес [tuches], co po polsku oznacza 'tyłek'.

Wracając do Leśmiana, odnotuję, że pod przekładem Ballady bezludnej autorstwa Bondariewskiego pojawiły się z kolei następujące komentarze:

Потрясающий оригинал! Потрясающий перевод! Если не трудно когда жил Болеслав Лесьмян? Огромное спасибо! Всего Вам самого наилучшего, Сёма ${ }^{7}$.

Стих хороший, но почему не рифмован. Ведь в оригинале есть рифмы. Это отход от Лесьмяна существенный⿱

Problem oceny przekładów pozostawię chętnym, tym bardziej że według mnie żadne $z$ tych trzech tłumaczeń nie jest najlepsze, a adekwatność, o której pisał Sitnitsky, dotyczy przede wszystkim płaszczyzny leksykalno-semantycznej. O wiele ciekawsze wydają się natomiast konstatacje natury socjologicznej. Z jednej strony warto zauważyć, że rosyjskojęzyczny Internet to pojęcie bardzo szerokie (Sitnitsky i Aleksiej Cwietkow mieszkają w USA, Bondariewski w Izraelu, Giennadij Zeldowicz, a także Władimir Stockman w Polsce), choć wspomniana już Wirtualis jest mieszkanką Moskwy. Z drugiej strony wypada zwrócić uwagę na pokolenie tłumaczy z wykształceniem technicznym. Oprócz wymienionych wcześniej, przedstawicielem nauk ścisłych był również zmarły w 2011 roku Anatolij

5 lebo35: Gratulacje! Z okazji urodzin i dobrego przekładu! / alsit25: Dziękuję! Dobry wariant to ma pan, a ja adekwatny do oryginału. Pan nawet słowa Czerwiec nie zrozumiał, co tam mówić o reszcie! / lebo35: Zostawiam Panu czerwiec. Pańskie odkrycie / [...] alsit25: .... lustra bywają krzywe! Widziałem dwa - w wykonaniu pańskim i niezapomnianej wirtuchalis. Alsit25 i Lebo35, https://alsit25.livejournal.com/177522.html\#comments (dostęp: 22.10.2017).

6 Zob. O. Griban (О. Грибан), Ай, словарь. Информаиионные технологии -это просто!, Litres 2017 [e-book], https://books.google.pl/books?id=FIIiDgAAQBAJ\&q==Компьютерный+вирус\&hl \#v=snippet\&q=Компьютерный\%20вирус\&f=false (dostęp: 30.10.2017).

7 Потрясающий... - Wstrząsający oryginał! Wstrząsające tłumaczenie! Jeśli to nie trudne - proszę mi powiedzieć, kiedy żył Bolesław Leśmian? Bardzo dziękuję! Życzę wszystkiego dobrego - Sioma. Zob. S. Ostrowski (С. Островский), Rе: Болеслав Лесьмян. «Безлюдная баллада» (Лев Бондаревский), 2005, http://www.poezia.ru/works/34220 (dostęp: 22.10.2017). Autorem komentarza jest Siemion Ostrowski.

8 Стих... - Wiersz dobry, ale dlaczego bez rymów. Przecież w oryginale są rymy. To poważne odejście od Leśmiana. A. Łukianow (А. Лукьянов), Re: Болеслав Лесьмян. „Безлюдная баллада" (Лев Бондаревский), 2005, http://www.poezia.ru/works/34220 (dostęp: 22.10.2017). 
Gieleskuł, który ukończył Moskiewski Instytut Przemysłu Naftowego i Gazownictwa, jest nim przekładający Leśmiana Siergiej Szorgin (doktor habilitowany nauk fizyko-matematycznych, łączący hobby translatorskie z pracą w Instytucie Informatyki Rosyjskiej Akademii Nauk). Nie znaczy to, że wśród tłumaczy nie ma humanistów. Jednym z najbardziej znanych jest Andriej Bazilewski, doktor habilitowany nauk filologicznych i redaktor wydanego w 2006 roku tomu przekładów wierszy Leśmiana. Na marginesie niniejszych rozważań pozwolę sobie zauważyć, że techniczne wykształcenie rosyjskich literatów, w tym tłumaczy literackich, jest częstym zjawiskiem, które zwykle, choć nie zawsze, w ZSRR było uwarunkowane politycznie ${ }^{9}$. Niemniej, niezależnie od miejsca zamieszkania i wykształcenia, tłumacze polskiej poezji popularyzują ją wśród czytelników znających język rosyjski.

Przyglądając się istnieniu Leśmiana w rosyjskojęzycznej przestrzeni internetowej, trzeba więc zwrócić uwagę na rosnącą ostatnio liczbę przekładów jego wierszy na rosyjski. W Internecie znajdujemy dane potwierdzające istnienie ogromnej, bo ponadtrzydziestoletniej przerwy między pojawieniem się pierwszego tomu rosyjskich tłumaczeń Leśmiana w 1971 roku $^{10}$ a zbiorami wydanymi niedawno, w latach $2006^{11}, 2013^{12}$ i $2014^{13}$. Pomijam tu tom wydany w 2004 roku w Polsce przez Zeldowicza ${ }^{14}$ oraz przekłady publikowane $\mathrm{w}$ rosyjskich antologiach poezji polskiej czy w czasopismach. Mimo to widoczne „zagęszczenie” rosyjskich tłumaczeń pozwala konstatować wzmożone zainteresowanie tą twórczością na terenie współczesnej Rosji i wśród czytelników rosyjskojęzycznych. $Z$ drugiej strony trzeba zauważyć, że jest to również związane z likwidacją barier cenzuralnych - brak politycznego zaangażowania poezji polskiego twórcy przestał być przeszkodą dla jej publikacji na terenie byłego ZSRR. Zresztą nawet data wydania pierwszego Leśmianowskiego tomu (1971) wskazuje na decyzję o publikacji podjętą już po tzw. odwilży chruszczowowskiej, kiedy pewne, wcześniej niedrukowane teksty mogły ujrzeć światło dzienne. Wypada też w kontekście Internetu zauważyć, że opublikowanie w nim licznych przekładów jest w jakimś sensie symptomatyczne - elektroniczne warianty wierszy nie są bowiem poddawane żadnej cenzurze, a czasem byłaby ona wskazana ze względu na artyzm,

9 W ZSRR przedstawiciele niektórych narodowości, zwłaszcza Żydzi, Niemcy, Tatarzy krymscy, Grecy, Turcy, mieli problemy z dostaniem się na studia, a przede wszystkim na studia humanistyczne.

10 B. Leśmian, Стихu, wstęp А. Гелескул, wybór Н. Богомолова, Москва 1971.

11 Тепże, Безлюдная баллада, или Слова для песни без слов, red. i wstęp А. Базилевский, Pułtusk-Москва 2006.

12 Tenże, Баллады и романсы, wybór i komentarz H.P. Малиновская, wstęp А.М. Гелескул, Санкт-Петербург 2013.

13 Tenże, Запоздалое признание, tłum. Г. Зельдович, Москва 2014.

14 Tenże, Zielony dzban. Wybór poezji w oryginale polskim i w rosyjskim tłumaczeniu Gennadija Zeldowicza/Зеленый жбан. Избранные стихи в польском оригинале и в русском переводе Геннадия Зельдовича, Torun 2004. 
a raczej jego brak w tłumaczeniu. To polityczne powiązanie (cenzura polityka wydawnicza) potwierdzają słowa Kseni Starosielskiej:

Były lata chude i tłuste - w zależności od sytuacji politycznej [...].

Najpierw, z początkiem pieriestrojki, my - tłumacze - wpadliśmy w stan euforii. Wszystko jest dozwolone, nareszcie można zlikwidować "białe plamy" [...] $]^{15}$.

Kolejna interesująca mnie kwestia to rodzaj informacji o polskim poecie, jakie pojawiają się przy okazji jego przekładu na rosyjski. Okazuje się, że poza poświęconym Leśmianowi hasłem w Wikipedii rosyjski czytelnik może znaleźć w przestrzeni elektronicznej także informacje innego rodzaju, choć nie zawsze najwyższej jakości. Na przykład pod zamieszczonym w 2012 roku na stronie Проза.py esejem Aleksa Bou Болеслаһ Лесьмян. Поэзия (Bolesław Leśmian. Poezja) ${ }^{16}$ przeczytamy następujące słowa Ludmiły Rogożewej-Karpowicz:

Господин Боу! Я, к сожалению, так и не поняла что это и зачем: сплошная, да к тому же плохая, компиляция из предисловий разных переводчиков Б. Лесьмяна плюс переводы стихов в основном без указания переводчиков. Что это не Ваши переводы, я знаю, т.к. Лесьмяна читала. Собственно и рецензия не нужна. Увы! Л. Рогожева ${ }^{17}$.

Odnotujmy, że Rogożewa sama pisze wiersze, tłumaczy poezję, w tym Leśmiana, jest emerytowanym wykładowcą języka rosyjskiego, a swoje teksty publikuje w Internecie, zapraszając czytelników do komentowania jej dokonań. Przedstawia się przy tym publiczności okolicznościowym wierszykiem, który pozwala jej dystansować się od dwóch największych poetek rosyjskich - Anny Achmatowej i Mariny Cwietajewej - i w jakimś stopniu tłumaczy przed czytelnikami ewentualne niedociągnięcia. Przytaczam jego pierwszą strofę wraz z tłumaczeniem na język polski:

15 K. Starosielska, Co czyta Rosjanin z literatury polskiej (dzień wczorajszy i dzień dziszejszy), [w:] Między oryginatem a przektadem, t. 4, Literatura polska w przektadzie, red. M. Filipowicz-Rudek, J. Konieczna-Twardzikowa, U. Kropiwiec, Kraków 1998, s. 12.

16 А. Bou (А. Боу), Болеслав Лесьмян. Поэзия, https://proza.ru/2012/06/19/1282 (dostęp: 22.10.2017).

17 Господин... - Panie Bou! Niestety, nie zrozumiałam, co to ma być i po co: zupełna i w dodatku fatalna kompilacja przedmów różnych tłumaczy B. Leśmiana, plus tłumaczenia wierszy, w większości bez wskazania tłumaczy. Że to nie Pana tłumaczenia wiem, bo Leśmiana czytałam. W zasadzie nawet recenzja nie jest potrzebna. No cóż! L. Rogożewa. Tamże (dostęp: 22.10.2017). W tekście używam nazwiska Rogożewa zgodnie z podpisem autorki. 
[Я не Марина...]

Я не Марина и не Анна: мне далеко до их высот. На ниве творческой незваной взросла: не роза, а осот ${ }^{18}$.
[Jam nie Marina...]

Jam nie Marina i nie Anna na szczyty te tak trudno wbiec. Wyrosłam tutaj nieproszona nie tyle róża, ile mlecz ${ }^{19}$. (tłum. A.B.)

Nie będę analizować przekładów autorstwa Rogożewej, odnotuję jednak, że na swojej stronie internetowej prezentuje ona trzydzieści trzy tłumaczenia samego tylko Leśmiana, co moim zdaniem sprawia, że warto bliżej przyjrzeć się jej twórczości.

Wypada także zauważyć, że tłumaczka ta, podobnie jak Cwietkow, jest autorką wstępu do własnych przekładów, zatytułowanego Поэт магии слова. O творчестве Б. Лесьмяна (Poeta magii słowa. O twórczości B. Leśmiana), w którym informuje:

\begin{abstract}
Летом 2009 года приятель подарил мне книжку Безлюдная баллада, или Слова для песни без слов польского поэта Болеслава Лесьмяна. Он привёз книгу мне на дачу, и мы вместе стали просматривать её. Польскую поэзию оба знали плохо, имя автора книги слышали впервые, но с первых же страниц поняли, что, несмотря на разный уровень публикуемых переводов, это поэт удивительный, самобытный, неординарный. Я настолько увлеклась его стихами, что захотелось прочитать Лесьмяна в оригинале, попробовать самой переводить с польского эти необычные стихи [...]. Всё дело было в том, что польского языка я не знала ${ }^{20}$.
\end{abstract}

Po ośmiu latach od tej publikacji na stronie Rogożewej poza przekładami z Leśmiana znajdujemy też Sonety krymskie Mickiewicza (niektóre w dwóch wersjach przekładowych) oraz tłumaczenia z angielskiego.

Wróćmy jednak do charakterystyki rosyjskojęzycznego Internetu, w którym pojawiają się także przedruki artykułów ze znanych czasopism, jak „Иностранная литература", gdzie opublikowano wstęp do tomu przekładów wierszy Leśmiana ${ }^{21}$, сzу „Новый мир”, gdzie znajdziemy wypowiedź wspo-

18 L. Rogożewa-Karpowicz (Л. Рогожева-Карпович), Я не Марина и не Анна..., https:// www.stihi.ru/avtor/kavardak\&book=10 (dostęp: 22.10.2017).

19 Tłum. moje - A.B.

20 Летом... - Latem 2009 roku przyjaciel podarował mi książkę Bezludna ballada, albo Stowa do pieśni bez słów polskiego poety Bolesława Leśmiana. Przywiózł mi tę książkę na działkę i zaczęliśmy ją razem przeglądać. Oboje prawie nie znaliśmy polskiej poezji, nazwisko autora książki słyszeliśmy pierwszy raz w życiu, ale od razu zrozumieliśmy, że niezależnie od nierównego poziomu publikowanych przekładów, to jest zadziwiający, samodzielny, oryginalny poeta. Tak wciągnęły mnie jego wiersze, że zapragnęłam przeczytać Leśmiana w oryginale i spróbować tłumaczyć te niezwykłe wiersze z polskiego [...] Problem w tym, że nie znałam polskiego. L. Rogożewa-Karpowicz (Л. Рогожева-Карпович), Поэт магии слова. O творчестве Б. Лесьмяна, https://www.stihi.ru/2013/01/08/3268 (dostęp: 22.10.2017).

21 A. Gieleskuł (А. Гелескул), „Телом после я стал, а сперва была рана”, [wstęp do:] Б. Лесьмян, Стихи, „Иностранная литература” 2006, nr 7, http://magazines.russ.ru/inostran/2006/7/le3.html (dostęp: 22.10.2017). 
mnianego już Cwietkowa, w następujący sposób wyjaśniającego czytelnikom rosyjskim, co skłoniło go do zainteresowania się przekładem polskiej poezji:

\begin{abstract}
В годы моей юности польский язык был для многих из нас своеобразным эквивалентом греческого для римлян, окном в культуру, к которой не было иного доступа. [...] польский был в основном транспортным средством, потому что в польских переводах, которые продавались в сети книжных магазинов „Дружба", можно было знакомиться с образцами западной литературы [...] Но даже в поезде, ожидая места назначения, поневоле знакомишься с попутчиками и входишь в их обстоятельства. Неожиданно оказалось, что этот польский поезд кое в чем интереснее места назначения - в первую очередь это касалось польской поэзии, которую я поначалу читал наугад, совершенно в ней не ориентируясь $[. . .]^{22}$.
\end{abstract}

Tego typu uwagi stosunkowo często występują w wypowiedziach rosyjskich tłumaczy z języka polskiego, będącego dla nich w przeszłości oknem na świat Zachodu. Obecnie takie przekłady częściej dokonywane są jednak z potrzeby serca, jak w przy padku Rogożewej, która specjalnie dla Leśmiana nauczyła się polskiego.

Należy także zwrócić uwagę na nazwiska tłumaczy pojawiające się na różnych stronach internetowych. Warto przy tym jeszcze raz wskazać na projekt „Век перевода”, gdzie publikowane są przede wszystkim prace uznanych tłumaczy, zwykle starszych, często już nieżyjących, jak Boris Pasternak czy Maria Pietrowych, choć także twórców współczesnych, jak zmarły niedawno Gieleskuł, a także Szorgin, Cwietkow, Zeldowicz. Wszystkich ich nobilituje publikacja na stronach wspomnianego projektu, ponieważ znalezienie się na liście jego autorów oznacza popularność i uznanie. Wypada tu wspomnieć, że w Rosji, a wcześniej w ZSRR bardzo często przekładem zajmowali się znani poeci. Tak też było w przypadku Pasternaka, Pietrowych czy Borisa Słuckiego. Teoretycznie miało to podnosić poziom tłumaczenia. Praktyka dowodzi jednak, że indywidualność poetycka może negatywnie wpływać na rezultat translacji, co nie jest tematem niniejszych rozważań.

Z kolei na stronach Сmuхu.py oraz Поэзия.py pojawiają najczęściej prace tłumaczy mniej znanych, zwykle publikujących wyłącznie w Internecie, chociaż znajdziemy tu także przekłady Zeldowicza. Niewątpliwym

22 В годы... - W czasach mojej młodości język polski był dla wielu z nas swoistym ekwiwalentem greki dla Rzymian, oknem do kultury, do której nie było swobodnego dostępu. [...] polski był dla nas przede wszystkim środkiem transportu, ponieważ to w polskich przekładach, sprzedawanych w sieci księgarni „Drużba”, można było zapoznać się z utworami literatury Zachodu [...] Ale nawet w pociągu, w oczekiwaniu na stację docelową poznaje się współpasażerów i wnika w ich problemy. Nieoczekiwanie okazało się, że ten polski pociąg w pewnych momentach jest ciekawszy od celu podróży - przede wszystkim dotyczyło to poezji polskiej, którą najpierw czytałem na oślep, zupełnie się w niej nie orientując [...]. А. Цветков, За переживших дно и берега..., „Новый мир” 2011, nr 10, http://magazines.russ. ru/novyi_mi/2011/10/le10.html (dostęp: 22.10.2017). 
wyróżnikiem wspomnianych stron jest natomiast aktualność zamieszczanych na nich propozycji translatorskich oraz możliwość konwersacji z ich autorami. Niektóre z nazwisk powtarzają się dość często, kiedy są to autorzy wielu przekładów, jak wspomniany już Bondariewski czy Wirtualis, która zamieściła na stronie internetowej piętnaście tłumaczeń wierszy Leśmiana, ale także dziesięć swoich wariantów tekstów Jeremiego Przybory oraz tłumaczenia z angielskiego i francuskiego. Zdarzają się także pojedyncze próby translatorskie, jak choćby w przypadku Jurija Sałatowa, który przełożył dwa wiersze Leśmiana ${ }^{23}$ czy Stockmana, twórcy jednego z rosyjskich wariantów Dziewczyny ${ }^{24}$.

Na popularność danego autora składają się jednak nie tylko tłumaczenia jego utworów, ale też wspomniane na wstępie opracowania naukowe, a nawet wzmianki o danym twórcy w rozważaniach z nim niezwiązanych, bądź związanych tylko pośrednio. Mam tu na myśli pochodzący z czasopisma "Огонёк" tekst Grigorija Krużkowa o przekładach autorstwa Pasternaka ${ }^{25}$, którego autor zauważa wprowadzenie do rosyjskiego wariantu Leśmianowskiego tekstu realiów odnoszących się do samego Pasternaka. Myślę też o artykułach okultysty, mistyka, pisarza, poety, tłumacza, literaturoznawcy, specjalisty z zakresu ezoteryki, znawcy alchemii, autora pieśni i kulturologa (taka charakterystyka pojawia się na poświęconych mu stronach), Jewgienija Gołowina, który odwołuje się w nich do dwóch wierszy polskiego poety, a mianowicie do Pity ${ }^{26}$, rozpatrywanej z punktu widzenia kabalistycznego obrazu Lilith, oraz Akteona ${ }^{27}$, którego tytułowy bohater widziany jest w kontekście tragicznej niewspółmierności monoteistycznej i politeistycznej koncepcji świata. Przy tym są one traktowane przede wszystkim jako ilustracja rozważań rosyjskiego mistyka o podpatrywaniu, obserwacji i postrzeganiu świata. Taki właśnie tytuł Подсматривание и наблюдение. Созерцание (Podpatrywanie i obserwacja. Postrzeganie) nosi esej Gołowina. Fragment dotyczący Leśmiana i Akteona rozpoczynają słowa:

Миф нельзя исследовать, интерпретировать, на основании мифа нельзя „приходить к выводам” научного, психологического либо нравственного характера, миф просто дает знать о своем присутствии - так молния предупреждает бузину: я иду, скрывайся. И это

23 В. Leśmian, Люблю тебе шептать слова..., tłum. Ю. Салатов, https://www.stihi. ru/2017/06/26/2991 (dostęp: 22.10.2017); tenże, Я стою здесь за дверями..., tłum. Ю. Салатов, https://www.stihi.ru/2017/06/26/2961 (dostęp: 22.10.2017).

24 В. Leśmian, Девушка, tłum. В. Стокман, http://v-stockman.livejournal.com/23308. html (dostęp: 22.10.2017).

25 G. Krużkow (Г. Кружков), Наизнанку, http://www.vavilon.ru/texts/prim/kruzhkov3-18.html (dostęp: 22.10.2017).

26 J.W. Gołowin (Е.В. Головин), Странные женщины. Эссе о Лилит и остальных женщинах, http://www.rossia3.ru/culture/speakihg/GolovinLilit (dostęp: 22.10.2017).

27 Tenże, Подсматривание и наблюдение. Созерцяание, http://golovinfond.ru/content/ veselaya-nauka-protokoly-soveshchaniy/podsmatrivanie-i-nablyudenie-sozercanie-0 (dostęp: 22.10.2017). 
дерево имеет свойство уклоняться от молнии. Мифы повествуют о героях божественного происхождения, и активное пространство мифа не наше пространство суть. Тогда зачем мифы? Возможно, для людей, чувствующих в крови раскаленную божественную тень, заброшенных в болота Гадеса, именуемых „земля”, „материальный мир", „современная эпоха” и т. д. Польский поэт Болеслав Лесьмян один из этих несчастных ${ }^{28}$.

Kończy go natomiast konkluzja:

\begin{abstract}
Люди новой эпохи склонны принимать за целое случайную комбинацию фрагментов, идентифицировать имя и носителя имени, сущность и её субстанцию - дело для греческой религии невозможное. Трагизм стихотворения Лесьмяна объясняется трагизмом монотеистического взгляда, несовпадения двух концепций человека.

Понятно, как во всякой сильной поэзии, здесь таится загадка: кто вброшен, втиснут в человеческое тело, кто это? ${ }^{29}$
\end{abstract}

Takie wzmiankowanie o Leśmianie w tekstach, które nie zawsze bezpośrednio odnoszą się do jego twórczości oraz przez autorów niebędących badaczami literatury polskiej, jak również odwołania do jego twórczości niewątpliwie są świadectwem dzisiejszej popularności polskiego poety.

Kończąc rozważania o przekładzie, chciałabym wskazać na inne jeszcze dowody tej popularności. Niewątpliwie warto tu odnotować pojawienie się Leśmianowskiego Gdybym spotkat ciebie znowu pierwszy raz... na koncercie poświęconym pamięci tłumaczki Marii Pietrowych, gdzie Swietłana Kriuczkowa deklamowała go w obu wersjach językowych ${ }^{30}$.

Jej przykładem z pewnością są również poświęcone Leśmianowi wiersze, napisane i opublikowane przez rosyjskich poetów w Internecie. Pierwszy

28 Mиф... - Mitu nie można badać, interpretować, na podstawie mitu nie można „wyciągać wniosków" naukowych ani wniosków o charakterze psychologicznym czy moralnym, mit po prostu daje znak swej obecności - w taki właśnie sposób błyskawica uprzedza dziki bez: nadchodzę, chowaj się. A drzewo to posiada zdolność uchylania się przed błyskawicą. Mity opowiadają o bohaterach boskiego pochodzenia, a aktywna przestrzeń mitu nie jest naszą przestrzenią. Po co więc istnieją mity? Możliwe, że są dla ludzi, którzy czują we krwi rozpalony boski cień, porzuconych na bagnach Hadesu, które nazywa się „ziemia”, „świat materialny", „epoka współczesna” itd. Polski poeta Bolesław Leśmian jest jednym z tych nieszczęśników. Tamże (dostęp: 22.10.2017).

29 Люди... - Ludzie nowej epoki skłonni są uznawać przypadkowe kombinacje fragmentów za całość, utożsamiać imię i jego nosiciela, istotę i jej substancję - to rzecz dla greckiej religii niemożliwa. Tragizm wiersza Leśmiana tłumaczy się tragizmem monoteistycznej wizji, niewspółmierności dwóch koncepcji człowieka. Oczywiście, że jak w każdej potężnej poezji skrywa się tu zagadka: kto został wrzucony, wciśnięty w ludzkie ciało, kto to jest? Tamże (dostęp: 22.10.2017).

30 В. Leśmian, Если бы тебя я Встретил в первый раз..., tłum. М. Петровых, deklamuje С. Крючкова, https://www.youtube.com/watch?v=E8WasmM3NRE (dostęp: 22.10.2017); tenże, Gdybym spotkat ciebie znowu pierwszy raz..., deklamuje С. Крючкова, https://www.youtube.com/ watch?v=B2AMemJFoSc (dostęp: 22.10.2017). 
z nich to utwór Dmitrija Szczedrowickiego zatytułowany Поэт Лесьмян (Poeta Leśmian) i będący typowym przykładem wiersza poświęconego innemu, uznanemu za autorytet poecie. Potwierdzają to zarówno słowa o spacerze z Leśmianem po łace, jak i wersy, gdzie Szczedrowicki mówi o wiązie Leśmiana, który o pół wieku wyprzedził jego (Szczedrowickiego) brzozę:

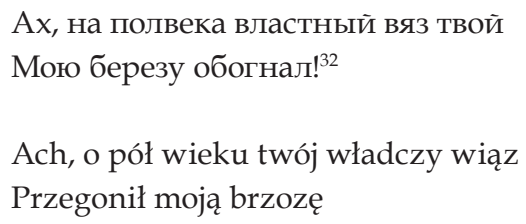

Poniżej prezentuję swój poetycki przekład wiersza Szczedrowickiego, w którym nastąpiły pewne transformacje, między innymi pół wieku ze względu na rym „skurczyło się" do ćwierćwiecza. Niemniej starałam się zachować w tłumaczeniu odniesienia do Leśmiana i jego twórczości, przede wszystkim takie motywy jak łąka sugerowana przez majowe trawy, personifikowana śmierć w oknie, mrok (ćma) i światło. Starałam się też odtworzyć grę słów związaną z imieniem Bolesław. Szczedrowicki wykorzystał tu możliwości dane przezjęzyk rosyjski i rozłożył imię Leśmiana na dwie cząstki skojarzone ze znaczeniami: 1. ból - ros. боль [bol'] znaczy 'ból', а больной [bol'noj] - 'chory', 'zbolały' oraz 2. sława - слава [slava], czyli ‘sława', ‘znaczenie’. W mojej propozycji pojawiły się słowa "sławny bólem sław”. Trzecią dominantą tłumaczenia stała się warstwa foniczna, dlatego też odwzorowałam rosyjski czterostopowy jamb z hiperkataleksą w wersach nieparzystych oraz schemat naprzemiennych rymów żeńskich i męskich, choć spadki żeńskie w wariancie docelowym nie są pełne.

Поэт Лесьмян

Стучатся в сердце - Видно, Лесьмян, Больной и славный Болеслав.

Нет, день не кончился, и мне с ним Еще бродить средь майских трав

Пугливо-детского славянства, А смерть кивает из окна... Ах, на полвека властный вяз твой Мою березу обогнал!

\section{Poeta Leśmian}

Ktoś stuka w serce - Pewnie Leśmian, Bolesław sławny bólem sław.

Nie, dzień się nie zakończył jeszcze, Pójdziemy w gąszcz majowych traw

Słowiaństwa, co w dziecinnej trwodze, A z okna ręką macha śmierć... Ach, wiąz twój władczy moją brzozę, Przegonił wszak o wieku ćwierć!

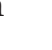


Что мастеришь? - Я строю клети (Пока не выброшен во тьму), Чтоб смыслы тьмы ловить при свете И просветлять по одному!...33
Co tam majstrujesz? - plotę sieci

(Póki mnie nie wrzucono w ćmę),

Chcę każdy z sensów mroku wzniecić, Schwytać je i rozświetlić chcę!....

Przy okazji tego tekstu warto jeszcze zwrócić uwagę na porównanie Leśmana do wiązu, a rosyjskiego ,ja" lirycznego do brzozy. To o tyle ciekawe, że twórczość Leśmiana trudno połączyć $\mathrm{z}$ wiązem, w przeciwieństwie do brzóz, które pojawiają się w niej dość często. Jednak brzoza uważana jest za symbol Rosji. Możliwe więc, że właśnie dlatego została ona skojarzona przez Szczedrowickiego ze sobą (autorem rosyjskim), z kolei wiąz stał się symbolem polskiego poety. Dlaczego właśnie wiąz - to już inne pytanie. Prawdopodobnie dla zbudowania powtarzającego się jambicznego schematu wiersza potrzebny był wyraz jednosylabowy i może dobrze, że Szczedrowicki nie wykorzystał w tym miejscu 'dębu' (ros. дуб [dub]), który skojarzony z Leśmianem mógłby zabrzmieć ironicznie.

Autorem drugiego wiersza jest wspominany już Gołowin, który jednak nie tyle poświęca swój tekst polskiemu twórcy, ile poetycko interpretuje jego wiersze. Utwór rosyjskiego autora, co niecodzienne nawet dla współczesnej poezji rosyjskiej, jest wierszem wolnym. Tekst ten przytaczam wraz z próbą „poetyzowanego" przekładu:

[В твоих волосах запутаны сосновые иглы...]

В твоих волосах запутаны сосновые иглы и ночи изрезаны осокой

Юноша останови свой неуверенный бег Пока пауки не высосали твоих зрачков

И фиолетовая чащоба не проросла через мозг

Зачем Ты оставил поляну Где цветы сладострастные и нетленные кружили тебя Водопадом своих сновидений и лукавый ручей

Дразнил тебя томной иронией женских изгибов
[W twoje włosy wplątały się igły sosnowe...]

W twoje włosy wplątały się igły sosnowe i noce turzycą pocięte

Młodzieńcze powstrzymaj swój niepewny bieg Zanim pająki nie wyssą twoich źrenic

A fioletowe chaszcze nie przerosną przez mózg

Czemuś zostawił polanę Gdzie okrążały cię kwiaty lubieżne i niezniszczalne Kaskadą sennych widziadeł a strumyk obłudny Drażnił tkliwą ironią kobiecych zakoli

\footnotetext{
33 Tamże,

34 D. Szczedrowicki, Poeta Leśmian, tłum. A. Bednarczyk.
} 
А теперь ты

разрываешь ногтями кору

И тянешь руки

к сосновым шишкам

словно они

Гесперидовы яблоки

и перед камнем

Что ржавой порос бородой

ты склоняешься как перед богом

И там где пространство

совпадает с тишиной

И в тишине золотыми прожилками

блестят крики сильванов

Лесная зеленая пена

шипя отступает

Образуя круг сумасшедший

где пляшет секунда

Юноша останови

свой неуверенный бег

В болоте гниет звезда

и жабы хохочут

И грязная ртуть

на сиреневых травах висит

В шпажнике и желтоцветах

бродит пьяная старуха

И космы седые шершавят

белесые вислые груди

И в черных глазах ее

плавает иней ресниц

Лови ее лови

Благословенна будь

ревнивая страсть к божеству

Бег через лес

и желание стать андрогином ${ }^{35}$
A teraz sam

pazurami rwiesz korę

I ręce wyciągasz

ku sosnowym szyszkom

jak gdyby były

jabłkami Hesperyd

i kamieniowi

Co rdzawą obrósł brodą

bijesz pokłony jak bogu

I tam gdzie się przestrzeń

utożsamia z ciszą

W ciszy żyłkami złotymi

lśnią sylwanów krzyki

Leśna piana zielona

już cofa się sycząc

I krąg tworzy obłędny

gdzie taniec sekundy

Młodzieńcze postrzymaj

swój niepewny bieg

W bagnie gdzieś gwiazda gnije

chichoczą ropuchy

I rtęć się brudna

zwiesza z liliowo-bzowych traw

W gladiolach brodzi i w jaskrach

jakaś pijana starucha

siwy strąk włosów ociera

białawą obwisłą pierś

I widzisz w czarnych oczach

jak płynie szron jej rzęs

Więc łap ją więc ją łap

O bądź błogosławiona

zazdrosna żądzy bóstwa

Bieg poprzez las

i pragnienie by stać się androgynem ${ }^{36}$.

(Tłum. A. Bednarczyk)
297

Do wiersza rozpoczynającego się słowami: [В твоих волосах запутаны сосновые иглы...] (pol. [W twoje włosy wplątały się igły sosnowe...]) rosyjski okultysta wplótł elementy interpretacji przypominające własne, odnotowywane już przeze mnie rozważania o Akteonie, dostosowując też pewne obrazy

35 J.W. Gołowin (Е.В. Головин), [В твоих волосах запутаны сосновые иглы...], http:// golovinfond.ru/content/tumany-chernyh-liliy\#10, (dostęp: 22.10.2017).

36 Tenże, [W twoje włosy wplątały się igły sosnowe...], tłum. A. Bednarczyk. 
do własnych wyobrażeń o Leśmianie i jego poezji widzianych w kontekstach mistycyzmu. Nawiązania do Akteona można doszukiwać się w pierwszym wersie, gdzie mowa o leśnym igliwiu - przypomnijmy Leśmianowskie: „Pokrwawiła się wieczność o leśne igliwie!"37, przede wszystkim jednak w końcowych wersach rozpatrywanego tekstu:

Благословенна будь

ревнивая страсть к божеству

Бег через лес

и желание стать андрогином ${ }^{38}$
O bądź błogosławiona

zazdrosna żądzy bóstwa

Bieg poprzez las

i pragnienie by stać się androgynem ${ }^{39}$

Jest to jednocześnie nawiązanie do Szewczyka, którego słowa:

Błogosławiony trud,

Z którego twórczej mocy $[\ldots]^{40}$

wydają się pobrzmiewać w cytowanym wyżej fragmencie wiersza Gołowina. W tekście tym można się jednak dopatrzeć i innych interpretacyjnych „ech” Leśmiana, a mianowicie odwołań do Zmór wiosennych czy Topielca, szczególnie w kontekście biegu przez las oraz przekształcenia (odczłowieczenia):

Biegnie dziewczyna lasem. Zieleni się jej czas...

Oto jej włos rozwiany, a oto - szum i las

$[\ldots]$

A teraz biegnie $\mathrm{w}$ jawę, przez las na lasu skraj $[\ldots]^{41}$

A on biegł wybrzeżami coraz innych światów,

Odczłowieczając duszę i oddech wśród kwiatów [... $]^{42}$

Tym bardziej że w Topielcu także polana i las upodobniają się do siebie:

W zwiewnych nurtach kostrzewy, na leśnej polanie,

Gdzie się las upodobnia łące niespodzianie $[\ldots]^{43}$.

37 B. Leśmian, Akteon, https://wolnelektury.pl/katalog/lektura/napoj-cienisty-akteon. html (dostęp: 30.10.2017).

38 J.W. Gołowin (Е.В. Головин), [В твоих волосах запутаны сосновые иглы...].

39 J.W. Gołowin (Е.В. Головин), [W twoje włosy wplątały się igły sosnowe...].

40 B. Leśmian, Szewczyk, https://pl.wikisource.org/wiki/Szewczyk_(Leśmian) (dostęp: 30.10.2017).

${ }^{41}$ Tenże, Zmory wiosenne, http://literat.ug.edu.pl/xxx/lesman/zmory.htm (dostęp: 30.10.2017).

42 Tenże, Topielec, http://literat.ug.edu.pl/xxx/lesman/topiel.htm (dostęp: 30.10.2017).

43 Tamże. 
W utworze tym można doszukać się również reminiscencji wszelkich Leśmianowskich łąk i polan („Зачем Ты оставил поляну” - „Czemuś zostawił polanę"). Nie ma jednak sensu mnożenie tych odniesień do polskiego poety, ponieważ nawiązania, o których mowa, nie muszą odwoływać się do konkretnego wiersza. Idzie tu raczej o nagromadzenie w rosyjskim tekście elementów obecnych w twórczości Leśmiana, takich choćby jak polana, las, cisza, zieleń, złoto, lśnienie (błyszczenie), które nie tylko występują u polskiego twórcy, ale często przenikają się nawzajem w jednym tekście, za przykład posłużyć może Las czy Łąka:

Lub ci może zielonym narzuci się złotem

Las, widziany przygodnie - niegdyś - mimolotem ${ }^{44}$

Czy pamiętasz, jak głowę wynurzyłeś z boru,

Aby nazwać mnie Łąką pewnego wieczoru? ${ }^{45}$.

U Gołowina obserwujemy to choćby w wersach:

И там где пространство

совпадает с тишиной

И в тишине золотыми прожилками

блестят крики сильванов

Лесная зеленая пена

шипя отступает
A teraz gdzie się przestrzeń utożsamia $\mathrm{z}$ ciszą W ciszy żyłkami złotymi lśnią sylwanów krzyki Leśna piana zielona już cofa się sycząc

Jednak, z drugiej strony, w utworze rosyjskiego autora pojawiły się charakterystyczne dla niego "ciemne”, pełne brzydoty, prawie turpistyczne obrazy, jak pająki wysysające oczy, chaszcze przerastające mózg, gwiazda gnijąca w bagnie, brudna rtęć, wreszcie pijana starucha i siwe kosmyki włosów, które ocierają (trąc, drapiąc) jej obwisłe piersi. Wypada skonstatować, że wiersz tylko do pewnego stopnia został zainspirowany spuścizną Leśmiana, która jedynie zainicjowała jego powstanie. Gołowin przede wszystkim wykorzystał tę twórczość dla poparcia swoich przemyśleń, podobnie jak uczynił to w cytowanym wcześniej eseju. Gdybyśmy jednak chcieli w wierszu rosyjskiego mistyka doszukiwać się Leśmiana, okaże się, że pająk Gołowina nie odpowiada temu z Ballady bezludnej, który „w nicość się nastawił, by pochwycić cień jej cienia”, że gnijąca gwiazda w żaden sposób nie nawiązuje do gwiazd lśmianowskich, że obwisła pierś staruchy nie może kojarzyć się z opiewanym przez polskiego poetę pięknem kobiecego ciała. Gdybyśmy

44 Tenże, Las, http://literatura.wywrota.pl/wiersz-klasyka/39318-boleslaw-lesmian-las. html (dostęp: 30.10.2017).

45 Tenże, Łąka, http://literat.ug.edu.pl/lesman/laka.htm (dostęp: 30.10.2017). 
natomiast chcieli odnaleźć słowa, które stały się pretekstem do nakreślenia obrazu obecnego w pierwszym wersie rosyjskiego utworu, najbliższy okaże się następujący fragment Łąki:

I było już wiadomo, że pułap sosnowy

Wonnym deszczem, jak obłok, pokropi nam głowy.

Trudno jednak uznać, że obrazy z wierszy Leśmiana i Gołowina są tożsame.

W kontekście rozważań o popularności twórcy Ballady bezludnej trzeba jeszcze wspomnieć, że prezentowany rosyjski wiersz pod tytułem Только Лесьмян (Tylko Leśmian) pojawił się w książce Gołowina Парагон ${ }^{46}$, a jako Болеславу Лесьмяну (Bolestawowi Leśmianowi) zyskał dwa różne opracowania muzyczne ( $\mathrm{w}$ formie melorecytacj $\mathrm{j}^{47}$ oraz piosenk $\mathrm{i}^{48}$ ).

Co jest miarą popularności danego twórcy? Jeśli istnienie w Internecie, to Leśmian jest $\mathrm{w}$ rosyjskojęzycznym Internecie popularny - w pisując $\mathrm{w}$ wyszukiwarkę jego nazwisko, uzyskamy informację o istnieniu 109 tysięcy stron, na których ono występuje. Otrzymamy też informację o poświęconych poecie publikacjach, które ukazały się drukiem, uzyskamy dostęp do wielu internetowych wypowiedzi na jego temat, w tym odnoszących się do profesjonalnych bądź amatorskich przekładów utworów Leśmiana. Moim zdaniem zarówno ich wielość, jak i rosnąca liczba tłumaczy świadczą o wzroście popularności, choć nie jest to wcale równoznaczne z wysoką jakością rosyjskich wersji. Tym bardziej że nie wszyscy tak samo ową jakość rozumieją.

Na jednej z rosyjskojęzycznych stron internetowych można odnaleźć anonimowy, podpisany jedynie pseudonimem Джейка (Dżejka) tekst o polskim poecie, który rozpoczyna się słowami:

На что угодно поспорю, что имя это широко неизвестно среди нас.

Однако несколько строк этого поэта знают многие - тут тоже готова на что угодно поспорить. Смотрите -

Я укрыться убийцам не дам,

Я их всех, я их всех обнаружу.

Я найду, я найду их. Но сам,

Сам я всех их, наверное, хуже.

46 J.W. Gołowin (Е.В. Головин), Лесьмян только, [w:] tegoż, Парагон, Москва 2013, s. 118.

47 Tenże, Болеславу Лесьмяну, oprac. muz. i wyk. Ядвига Розенпаулис, https://www. realmusic.ru/songs/1392338 (dostęp: 30.10.2017).

48 Tenże, Болеславу Лесъмяну, oprac. muz. i wyk. Вилли Семенов, http://elmikon. online/?mp3-music $=\% \mathrm{D} 1 \% \mathrm{C} 5 \% \mathrm{CC} \% \mathrm{C} 5 \% \mathrm{CD} \% \mathrm{CE} \% \mathrm{C} 2+\% \mathrm{C} 2 \% \mathrm{C} 8 \% \mathrm{CB} \% \mathrm{CB} \% \mathrm{C} 8 \&$ page $=6$ (dostęp: 30.10.2017). 
Где-то что-то такое слышали, правда? Ну конечно, Пастернак. А что и откуда... А вот оттуда! Из стихотворения польского поэта Болеслава Лесьмяна Сестре... в переводе Пастернака ${ }^{49}$.

Wspomniane przez Dżejkę słowa Leśmiana brzmią w oryginale:

Winnych wskazać potrafię!... I nikt się nie broni!...

I ten - i ta - i ów!...

I ja sam! Ja - najbardziej, choć wiem, że i oni!

I ja - i oni znów... ${ }^{50}$

Autorka anonimowego tekstu dostrzega różnice między wariantem polskim i rosyjskim, typowe zresztą dla translatorskiej działalności Pasternaka, takie choćby jak wskazanie winnych w oryginale oraz ich ukrywanie się w tłumaczeniu. Nawiasem mówiąc, ujawnianie odstępstw Pasternaka od oryginału jest trendem nowym, który pojawił się w ostatnich latach. Wcześniej krytycy bądź zachwycali się artyzmem jego tłumaczeń, mając rację o tyle, o ile jego rosyjskie warianty to wspaniałe wiersze, bądź milczeli, nie chcąc, jak ujął to Jurij Lifszyc analizujący jeden z przekładów z gruzińskiego, „psuć sobie reputacji krytyką rodzimego klasyka"51.

Tekst Dżejki zamyka akapit cytujący inne słowa polskiego poety:

Он создал утликов, снигорбиков, сумеркунов, чмуров... Описывать его стихи и не подумаю даже. Читайте. Вот, например [...] „Либо ты птица, либо нет! Нельзя быть птицей наполовину! Неполноценное крыло перестает быть крылом". Он был - птицей ${ }^{52}$.

Słowa te dowodzą, że anonimowa autorka zachwyca się twórczymi dokonaniami Leśmiana. Jednak w jego tekstach nie ma utlików ani snigoborików (nawiasem mówiąc, literówka Dżejki zmienia znaczenie neologizmu: o ile гроб znaczy 'trumna', o tyle горб to 'garb' i w efekcie śnigrobik przekształcił

49 На что угодно - Założę się o cokolwiek, że to imię jest nam szeroko nieznane. Jednak kilka wersów poety zna wielu - tu też gotowa jestem założyć się o cokolwiek. Patrzcie [Я укрыться убийцам не дам, / Я их всех, я их всех обнаружу / Я найду, я найду их. Но сам, / Сам я всех их, наверное, хуже]. Gdzieś coś takiego słyszeliście, prawda? No oczywiście, Pasternak. A co i skąd... A stąd! Z wiersza polskiego poety Bolesława Leśmiana Do siostry... w przekładzie Pasternaka. Джейка, Болеслав Лесьмян, http://www.my-works.org/node/80 (dostęp: 22.10.2017); w słowie снигорбиков literówka - powinno być снигробиков.

50 B. Leśmian, Do siostry, https://wolnelektury.pl/katalog/lektura/napoj-cienisty-do-siostry.html (dostęp: 30.10.2017).

51 J.I. Lifszyc (Ю.И. Лифшиц), „Синий цвет” Николоза Бараташвили в переводе Бориса Пастернака. Между Сииллой и Харибдой, 2015, http://www.poezia.ru/works/116146 (dostęp: 30.10.2017).

52 Он создал... - Stworzył utlików, snigorbików, sumierkunów, czmurów... Nawet nie spróbuję opisywać jego wierszy. Czytajcie. Na przykład [...] „Albo jesteś ptakiem, albo nie! Nie można być ptakiem w połowie! Niepełnowartościowe skrzydło przestaje być skrzydłem”. On był ptakiem. Dżejka (Джейка), Болеслав Лесьмян. 
się w śnigarbika), nie ma też sumierkunów. Wymienione w internetowej wypowiedzi postaci to w oryginale: Znikomek, Śnigrobek, Zmierzchun oraz Czmur. I tylko ten ostatni, którego odpowiednik Чмyp w języku rosyjskim istnieje, jest regionalizmem pskowskim i oznacza człowieka zgłupiałego lub w stanie odurzenia alkoholowego, a także samo odurzenie, upicie się ${ }^{53}$. W związku z tym zachodzi prawdopodobieństwo, że Leśmian, który znał rosyjski, zapożyczył słowo чмyp, transkrybując je na łacinkę, a rosyjski odpowiednik jest niczym innym, jak tylko powrotem do oryginału. Pozostałe neologizmy zostały wykreowane przez tłumaczy na podstawie języka rosyjskiego:

a. odpowiednik Znikomka - Утлик [utlik] powstał na bazie przenośnego znaczenia przymiotnika утлый - 'biedny', 'nędzny', 'żałosny', a więc także 'znikomy', do którego dodano sufiks -ик [-ik], со w języku rosyjskim tworzy zdrobnienie do rzeczowników rodzaju męskiego;

b. odpowiednik Śnigrobka - Снигробик - skonstruowany został podobnie jak jego polski pierwowzór, to kontaminacja czasownika снить [snit'] - 'śnić' i rzeczownika гроб [grob] - 'trumna', choć nie do końca tożsama z oryginalnym: „śnić” i „grób”. Do do tego tworu (zlepka) dołączono ten sam, co w przypadku poprzedniego neologizmu sufiks -ик [-ik]. Dodajmy, że sens danego obrazu pozostał taki sam jak w oryginale, a tłumacz twórczo wykorzystał podobieństwo foniczne grób - гроб;

c. odpowiednik Zmierzchuna - Сумеркун został zbudowany na podstawie słownikowego odpowiednika polskiego rzeczownika zmierzch - сумерки opatrzonego sufiksem -ун [-un], co oznacza osobę zdolną do określonego działania. W tym przypadku dodano go do rzeczownika, warto jednak dodać, że istnieje też rosyjski czasownik смеркаться - 'zmierzchać się'. Znaczenie imienia Сумеркун nie jest więc dla rosyjskiego czytelnika tajemnicą.

Niezależnie od sposobu utworzenia rosyjskich neologizmów trzeba przyznać, że są one funkcjonalnymi odpowiednikami nazw stworzeń z wierszy polskiego poety, a tłumacze, kreując je, wykorzystali możliwości dane przez język docelowy. W tym sensie są to więc twory przekładowców, a nie Leśmiana.

Z kolei przytoczone przez Dżejkę słowa polskiego poety pochodzą ze szkicu Z rozmyślań o poezji: „Albo się jest ptakiem - albo się nim nie jest! Nie ma ptaków połowicznych! Skrzydło niecałkowite przestaje być skrzydłem”"54.

Największa różnica między oryginałem a tłumaczeniem dotyczy zastąpienia polskiego „niecałkowite” rosyjskim „niepełnowartościowe” (неполноценное), choć przekład, odbiegając nieco od znaczeń poszczególnych

53 Zob. np. В.И. Даль (W.I. Dal), Толковый словарь живаго великорусского языка http:// slovardalja.net/word.php?wordid=43130 (dostęp: 30.10 .2017 ).

54 B. Leśmian, Z rozmyślań o poezji, [w:] tegoż, Szkice literackie, oprac., wstęp J. Trznadel, Warszawa 1959, s. 78. 
składowych oryginału, oddaje jego sensy jako całości. Nie będę natomiast dyskutować z Dżejką o tym, czy Leśmian był, czy też nie był ptakiem.

Wskazane możliwości zaistnienia poety w rosyjskojęzycznym Internecie dowodzą wzrostu jego popularności wśród rosyjskich czytelników. Podobną rolę pełnią też przytoczone anonimowe romantyczno-naiwne enuncjacje. Niewątpliwie potwierdzają one możliwość popularyzowania danej twórczości dzięki narzędziom, jakie daje Internet, poświadczając również tezę o powodzeniu, jakim cieszy się twórczość Leśmiana w Rosji, choć z pewnością nie we wszystkich środowiskach. Nie wszyscy przecież lubią poezję...

Kończąc już rozważania o popularności polskiego poety w rosyjskiej przestrzeni cyfrowej, trzeba dodać, że odnajdujemy w niej również informacje o wierszach pisanych przez Leśmiana po rosyjsku. Są to zarówno studia badawcze odnoszące się do tych utworów, na przykład artykuł Natalii Anaprejenko ${ }^{55}$, która twórczości tego poety i Maksima Bogdanowicza poświęciła rozprawę doktorską ${ }^{56}$, jak i publikacje omawianych tekstów: poematu Песнu Василисы Премудрой (Pieśni przemądrej Wasylisy) oraz cykli Лунное похмелье (Księżycowe upojenie) і Волны живые (Żywe fale) ${ }^{57}$. Niektóre z wierszy wchodzących skład tych cykli otrzymały formę piosenki, przykładem może być Hour $(\text { Noc })^{58}$.

W Internecie pojawiła się także informacja o Przygodach Sindbada Żeglarza, które pod tytułem Новые приключения Синдбада Морехода (Nowe przygody Sindbada Żeglarza) ukazały się w rosyjskim tłumaczeniu Jurija Wronskiego w 1992 roku $^{59}$. Temu ostatniemu powiadomieniu towarzyszą słowa wydawcy o książce „napisanej przez wspaniałego, niedocenionego jeszcze u nas polskiego poetę" ${ }^{\prime \prime 0}$. Niewątpliwie także ten fakt potwierdza nowe widzenie przez Rosjan Leśmiana oraz dążenie do popularyzacji jego twórczości wśród potencjalnych czytelników. Popularyzacji, co istotne, rosnącej, bowiem nazwisko poety pojawia się - jak wcześniej wskazałam - na 109 tysiącach rosyjskojęzycznych stron internetowych. To liczba większa niż w przypadku chętnie czytanego w Rosji i ZSRR Juliana Tuwima (106 tysięcy) ${ }^{61}$, większa też niż w przypadku Wisławy Szymborskiej (niecałe 49 tysięcy).

55 N.J. Anaprejenko (Н.Я. Анапреенко), Русскоязычные стихи Б. Лесьмяна, [w:] Projekt: ЭБ БГУ, kolekcja: Мир языков. Ракурс и Перспектива, 2010, http://elib.bsu.by/handle/123456789/21416 (dostęp: 22.10.2017).

56 N.J. Anapejenko (Н.Я. Анапрэенка), Творчыя індывідуальнасиі Б. Лесьмяна і М. Багдановіча: параўнальна-тыпалагічны аспект, promotor М.М. Хмяльніцкі, Мінск 2014.

57 Русские стихи Болеслава Лесьмяна (В. Leśmian, Песни Василисы Премудой, Лунное похмелие, Волны живые), https://fantlab.ru/blogarticle30066 (dostęp: 22.10.2017).

58 Zob. np. B. Leśmian, Ночь, wyk. Сергей Горковенко, http://mp3zv.me/music/\%D0\%91\%D0\%BE\%D0\%BB\%D0\%B5\%D1\%81\%D0\%BB\%D0\%B0\%D0\%B2+\%D0\%9B\%D0\%B5\% D1\%81\%D1\%8C\%D0\%BC\%D1\%8F\%D0\%BD (dostęp: 30.10.2017).

59 В. Leśmian, Новые приключения Синдбада Морехода, tłum. Ю. Вронский, Московский рабочий, Москва 1992.

60 Oт издателя, https://www.ozon.ru/context/detail/id/5552691 (dostęp: 30.10.2017).

61 Tuwim znany jest jednak przede wszystkim jako autor wierszy dla czytelnika dziecięcego. 
Sama liczba stron internetowych nie decyduje oczywiście o niczyjej popularności. Tym bardziej że dane nazwisko może pojawić się na nich w bardzo różnych kontekstach. Niemniej liczba ta, a także owe „różne konteksty”, pozwalają zorientować się w tendencji, bo o uznaniu, jakim cieszy się dany autor, świadczy, jak już wspominałam, również przytaczanie jego nazwiska w wypowiedziach, które pozornie wcale go nie dotyczą. Dlatego właśnie w charakterze deseru pozwalam sobie zacytować słowa tłumaczki poezji angielskiej i polskiej Aleksandry Pietrowej, która pod pseudonimem akula_dolly ${ }^{6}$, wypowiadając się o rosyjskich tłumaczeniach Norwida, mówi: „В русских переводах Норвиду не повезло - как и великому Болеславу Лесьмяну, как и всей великой польской поэзии, как и вообще польской литературе"63.

To znamienne słowa i, jak myślę, pozwalają nam one żywić nadzieję na odrobinę szczęścia w przyszłości. Tym bardziej że Leśmian w rosyjskim Internecie to zjawisko bezsprzecznie nowe. Dlatego też nowe i nowatorskie są wszelkie jego odczytania, nie tylko translatorskie.

\section{B I B LIO GR A F I A}

akula_dolly (Петрова А.), 2007, 24 сентября, http://akula-dolly.livejournal. com/114743.html (dostęp: 30.10.2017).

alsit25 (Alex Sitnitsky), 2016, https://alsit25.livejournal.com/177522.html\#comments (dostęp: 22.10.2017).

Anaprejenko N.J. (Анапреенко Н.Я.), 2010, Русскоязычные стихи Б. Лесьмяна, [w:] Projekt: ЭБ БГУ, kolekcја: Мир языков. Ракурс и Перспектива, http://elib.bsu. by/handle/123456789/21416 (dostęp: 22.10.2017).

Anaprejenko N.J. (Анапрэенка Н.Я.), 2014, Творчыя індывідуальнасиі Б. Лесьмяна і М. Багдановіча: параунальна-тыпалагічны аспект, promotor М.М. Хмяльніцкі, Мінск 2014.

Bou А. (Боу А.), Болеслав Лесьмян. Поэзия, https://proza.ru/2012/06/19/1282 (dostęp: 22.10.2017).

Cwietkow A.Р. (Цветков А.П.), За переживших дно и берега, [wstęp do:] Б. Лесьмян, Стихи, tł. А.П. Цветков, „Новый мир” 2011, nr 10, http://magazines.russ.ru/ novyi_mi/2011/10/le10.html (dostęp: 22.10.2017).

Dżejka (Джейка), Болеслав Лесьмян, http://www.my-works.org/node/80 (dostęp: 22.10.2017).

Dal W.I. (Даль В.И.), Толковый словарь живаго великорусского языка http://slovardalja.net/word.php?wordid=43130 (dostęp: 30.10.2017).

62 Акула [akuła] - rekin.

63 В русских... - Norwid nie miał szczęścia do rosyjskich przekładów, podobnie jak nie miał go wielki Bolesław Leśmian, jak nie miała cała poezja polska i cała polska literatura. Akula_dolly [Петрова А.А.], 24 сентября, 2007, http://akula-dolly.livejournal.com/114743. html (dostęp: 30.10.2017). 
Gieleskuł A.M. (Гелескул А.М.), Телом после я стал, а сперва была рана, [wstęp do:] Б. Лесьмян, Стихи, „Иностранная литература” 2006, nr 7, http://magazines. russ.ru/inostran/2006/7/le3.html (dostęp: 22.10.2017).

Gołowin J.W. (Головин Е.В.), Странные женщины. Эссе о Лилит иостальных женщинах, http://www.rossia3.ru/culture/speakihg/GolovinLilit (dostęp: 22.10.2017).

Gołowin J.W. (Головин Е.В.), Подсматривание и наблюдение. Созериание, http:// golovinfond.ru/content/veselaya-nauka-protokoly-soveshchaniy/podsmatrivanie-i-nablyudenie-sozercanie-0 (dostęp: 22.10.2017).

Gołowin J.W. (Головин Е.В.), Болеславу Лесьмяну, http://golovinfond.ru/content/ tumany-chernyh-liliy\#10 (dostęp: 22.10.2017).

Gołowin J.W. (Головин Е.В.), Лесьмян только, [w:] J.W. Gołowin, Парагон, Москва 2013, s. 118.

Gołowin J.W. (Головин Е.В.), Болеславу Лесьмяну, оprac. muz. i wyk. Ядвига Розенпаулис, https://www.realmusic.ru/songs/1392338 (dostęp: 30.10.2017).

Gołowin J.W. (Головин Е.В.), Болеславу Лесьмяну, oprac. muz. i wyk. Вилли Семенов, http://elmikon.online/?mp3-music=\%D1\%C5\%CC\%C5\%CDCE\%C2+ \%С2\%C8\%CB\%CB\%C8\&page=6 (dostęp: 30.10.2017).

Griban О. (Грибан О.), Ай, словарь. Информационные технологии - это просто!, Litres 2017, https://books.google.pl/books?id=FIIDgAAQBAJ\&printsec=frontcover\&hl=pl\&source=gbs_ge_summary_r\&cad $=0 \# \mathrm{v}=$ onepage\&q\&f=false $(\mathrm{do}-$ stęp: 30.10.2017).

Jermaszowa I., Polska poezja w rosyjskim dwugłosie O ttumaczeniach Natalii Astafjewej i Wladimira Britaniszskiego, Poznań 2016.

Kaźmierczak M., Przekład w kręgu intertekstualności, Warszawa 2012.

Krużkow G.M. (Кружков Г.М.), Наизнанку, http://www.vavilon.ru/texts/prim/ kruzhkov3-18.html (dostęp: 22.10.2017).

Leśmian B., Akteon, https://wolnelektury.pl/katalog/lektura/napoj-cienisty-akteon.html (dostęp: 30.10.2017).

Leśmian B., Do siostry, https://wolnelektury.pl/katalog/lektura/napoj-cienisty-do-siostry.html (dostęp: 30.10.2017).

Leśmian B., Gdybym spotlkat ciebie znowu pierwszy raz..., deklamacja С. Крючкова, https://www.youtube.com/watch?v=B2AMemJFoSc (dostęp: 22.10.2017).

Leśmian B., Las, http://literatura.wywrota.pl/wiersz-klasyka/39318-boleslaw-lesmian-las.html (dostęp: 30.10.2017).

Leśmian B., Łąka, http://literat.ug.edu.pl/lesman/laka.htm (dostęp: 30.10.2017).

Leśmian B., Szewczyk, https://pl.wikisource.org/wiki/Szewczyk_(Leśmian) (dostęp: 30.10.2017).

Leśmian B., Szkice literackie, oprac., wstęp J. Trznadel, Warszawa 1959.

Leśmian B., Topielec, http://literat.ug.edu.pl/xxx/lesman/topiel.htm (dostęp: 30.10.2017).

Leśmian B., Zielony dzban / Зеленый жбан. Избранные стихи в польском оригинале и в русском переводе Геннадия Зельдовича, Torun 2004.

Leśmian B., Zmory wiosenne, http://literat.ug.edu.pl/xxx/lesman/zmory.htm (dostęp: 30.10.2017).

Leśmian B., Баллады и романсы, Петербург 2013.

Leśmian B., Безлюдная баллада, или Слова для песни без слов, Москва 2006. 
Leśmian В., Девушка, tłum. В. Стокман, http://v-stockman.livejournal.com/23308. html (dostęp: 22.10.2017).

Leśmian B., Если бы тебя я встретил в первый раз..., tłum. М. Петровых, deklamacja C. Крючкова, https://www.youtube.com/watch?v=E8WasmM3NRE (dostęp: 22.10.2017).

Leśmian В., Запоздалое признание, tłum. Г. Зельдович, Москва 2014.

Leśmian В., Люблю тебе шептать слова..., tłum. Ю. Салатов, https://www.stihi. ru/2017/06/26/2991 (dostęp: 22.10.2017).

Leśmian В., Новые приключения Синдбада Морехода, tłum. Ю. Вронский, Москва 1992.

Leśmian В., Ночь, wyk. Сергей Горковенко, http://mp3zv.me/music/\%D0\%91\%D0\%BE\%D0\%BB\%D0\%B5\%D1\%81\%D0\%BB\%D0\%B0\%D0\%B2+\%D 0\%9B\%D0\%B5\%D1\%81\%D1\%8C\%D0\%BC\%D1\%8F\%D0\%BD (dostęp: 30.10.2017).

Leśmian B., Стихи, wstęp А. Гелескул, wybór Н. Богомолова, Москва 1971.

Leśmian В., Я стою здесь за дверями..., tłum. Салатов Ю., https://www.stihi. ru/2017/06/26/2961 (dostęp: 22.10.2017).

Lifszyc J.I. (Лифшиц Ю.И.), „Синий иъвет” Николоза Бараташвили в переводе Бориса Пастернака, 2015, http://www.poezia.ru/works/116146 (dostęp: 30.10.2017).

Łukjanow A. (Лукьянов A.), Re: Болеслав Лесьмян. Безлюдная баллада. (Лев Бондаревский), 2005, http://www.poezia.ru/works/34220, (dostęp: 30.10.2017).

Ostrowski S. (Островский C.), Re: Болеслав Лесьмян. Безлюдная баллада. (Лев Бондаревский), 2005, http://www.poezia.ru/works/34220 (dostęp: 30.10.2017).

Rogożewa-Karpowicz L.L. (Рогожева-Карпович Л.Л.), Я не Марина и не Анна..., https://www.stihi.ru/avtor/kavardak\&book=10 (dostęp: 22.10.2017).

Rogożewa-Karpowicz L.L. (Рогожева-Карпович Л.Л.), Поэт магии слова. О творчестве Б. Лесьмяна, https://www.stihi.ru/2013/01/08/3268 (dostęp: 22.10.2017).

Starosielska K., Co czyta Rosjanin z literatury polskiej (dzień wczorajszy i dzień dziszejszy), [w:] Między oryginałem a przekładem, t. 4, Literatura polska w przekładzie, red. M. Filipowicz-Rudek, J. Konieczna-Twardzikowa, U. Kropiwiec, Kraków 1998, s. 11-15.

Szczedrowicki D.W. (Щедровицкий Д.В.), Поэт Лесьмян, http://shchedrovitskiy. ru/AirFingers.php?page=2 (dostęp: 22.10.2017).

Классика_, Болеслав Лесьмян, [w:] Стихи для ююDей, http://stihidl.ru/ poem/323803 (dostęp: 22.10.2017).

Oт издателя, https://www.ozon.ru/context/detail/id/5552691 (dostęp: 30.10.2017).

Русские стихи Болеслава Лесьмяна (Б. Лесьмян, Песни Василисы Премудой, Лунное похмелие, Волны живые), https:/fantlab.ru/blogarticle30066 (dostęp: 22.10.2017). 


\section{STRESZCZENIE}

Celem podjętych badań było uzupełnienie wcześniejszych ustaleń różnych badaczy o zaistnieniu twórczości Bolesława Leśmiana w Rosji, a przede wszystkim w Rosji dzisiejszej, o relację dotyczącą przestrzeni Internetu. Przeprowadzona analiza dotyczyła zarówno uznanych stron internetowych, prezentujących przekłady literatury obcojęzycznej na język rosyjski, jak i wybranych stron autorskich, na których zamieszczono amatorskie tłumaczenia, a także stron, na których pojawiły się różnego rodzaju wzmianki o polskim poecie.

W artykule odniesiono się także do problematyki popularyzacji twórczości polskiego poety i wykorzystania tej twórczości jako podstawy dla własnych utworów literackich bądź wypowiedzi filozoficznych.

Zostały w nim też odnotowane zaistniałe w przestrzeni Internetu, a poświęcone Leśmianowi wiersze oraz utwory wokalne, będące rezultatem stworzenia kompozycji muzycznych do tych tekstów, co niewątpliwie jest dowodem jego popularności wśród rosyjskojęzycznych internautów.

\section{Słowa kluczowe}

Leśmian, Internet, Rosja, przekład, popularność

\section{SUMMARY}

\section{Bolesław Leśmian in the Internet in Russian and the issue of popularity}

The aim of the research was to extend the previous findings of different scholars concerning the emergence of Bolesław Leśmian's literary output in Russia, particularly the Russia of today, by including the aspect of the Internet. The conducted analysis concerned both renowned Russian websites which present renditions of foreign literature into Russian and selected authorial websites publishing amateur translations as well as Internet sites which featured different kinds of comments about the Polish poet.

The article also makes references to the issue of popularization of the Polish poet's literary output and using this output as some grounds for new literary works or philosophical writing.

It also gives a record of poems and vocal works devoted to Leśmian which came into being in the space of the Internet through creation of musical compositions to these texts, which undoubtedly proves the poet's popularity among Russian-speaking Internet users.

\section{Keywords}

Leśmian, Internet, Russia, translation, popularity 